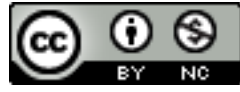

Jurnal Pendidikan Ilmu Pengetahuan Sosial Indonesia is licensed under A Creative Commons Attribution-Non Commercial 4.0 International License.

\title{
Strategi Pembelajaran Berbasis Blended Learning di Perguruan tinggi
}

\author{
Rini Setyowati \\ 1) STKIP Singkawang, Singkawang, Indonesia \\ E-mail:rini1989setyowati@gmail.com
}

\begin{abstract}
Abstrak. Tujuan dari penelitian ini adalah mengetahui upaya strategi pembelajaran berbasis blended learning dalam mata kuliah Pengembangan Pembelajaran IPS di SD di STKIP Singkawang. Model blended learning yang dikembangan dalam mata kuliah Pengembangan Pembelajaran IPS di Prodi PGSD STKIP Singkawang dilakukan dengan perpaduan tatap muka yang dapat memfasilitasi mahasiswa dengan kehadiran dosen untuk mengembangkan rasa kehadiran dan kenyamanan sosial, dalam tatap muka dilakukan untuk membahas kesulitan- kesulitan mahasiswa dalam proses pembelajaran. Dalam proses pembelajaran menggunakan modul offline mengenai konsep- konsep dasar IPS di SD sehingga mahasiswa diharapkan mampu menggunakan teknologi secara offline. Pembelajaran di kelas juga dilaksanakan dengan model online dengan memanfaatkan edmodo sebagai sarana berinteraksi ketika mahasiswa tidak di kampus. Edmodo dapat digunakan sebagai sarana mahasiswa bertanya, mengirimkan tugas, dan dosen dapat juga mengirimkan bahan dan tugas melalui edmodo. Dalam pengembangan blended learning yaitu pembuatan modul offline menggunakan software Ncesoft Flip Book Maker.
\end{abstract}

Kata Kunci: strategi, pembelajaran, blended learning

\section{INTRODUCTION}

Perguruan Tinggi merupakan salah satu ujung tombak dalam pendidikan di Indonesia. Perkembangan teknologi dalam abad 21 berbeda dengan abad industri. Pada era digital, dosen dan mahasiswa dituntut untuk menguasai teknologi sehingga ilmu pengetahuan bisa ditransfer lebih cepat. Salah satu tantangan yang dihadapi oleh Sekolah Keguruan dan Ilmu Pendidikan adalah kemampuan untuk menyiapkan lulusan S1 yang mampu beradaptasi dengan perubahan yang semakin cepat dalam bidang pendidikan karena lulusan dihadapkan dengan siswa- siswa generasi $\mathrm{Z}$ yang berbeda dengan generasi sebelumnya. Pengajaran- pengajaran konvensional di kampus tentu sudah tidak relevan dengan perkembangan teknologi.

Keterampilan- keterampilan yang diperlukan dalam abad 21 menurut Galbreth (1999) meliputi keterampilan komunikasi, kreativitas, dan inovasi, kerjasama dan pemberdayaan, literasi teknologi informasi, kemampuan visual, pemecahan masalah, pengambilan keputusan, pengembangan dan pengelolaan pengetahuan, serta kecerdasan. Keterampilan yang dulu popular yaitu $3 \mathrm{M}$ yaitu membaca, menulis, dan menghitung sudah harus berubah menjadi 3T yaitu teknologi, tim, dan transfer.

Penelitian dilaksanakan di STKIP Singkawang pada tahun 2019 selama satu semester pada mata pelajaran Pengembangan Pembelajaran IPS di SD. Pembelajaran IPS adalah telaah interaksi antara individu dan masyarakat dengan lingkungan (fisik 
dan budaya) dengan tujuan membina anak didik menjadi warga negara yang baik, yang memiliki pengetahuan, keterampilan, dan kepedulian sosial yang berguna bagi dirinya serta bagi masyarakat dan negara. Peneliti mencoba mengintegrasikan pembelajaran IPS dengan mengajarkan pembelajaran blended learning dalam proses pembelajaran.

\section{METODE}

Penelitian menggunakan metode penelitian kualitatif dengan jenis penelitian studi kasus. Penelitian dilaksanakan di STKIP Singkawang pada tahun 2019 selama satu semester pada mata pelajaran Pengembangan Pembelajaran IPS di SD. Data diambil menggunakan metode wawancara mendalam. Wawancara dilakukan kepada dua dosen pengajar IPS dan lima mahasiswa PGSD yang telah mengikuti perkuliahan Pengembangan Pembelajaran IPS di SD. Urutan penelitian adalah: 1.) Proses Pengambilan Data, 2) Reduksi Data, 3) Mendisplay Data, 4) Penarikan Kesimpulan. Secara sederhana dapat digambarkan tahapan analisis penelitian ini adalah sebagai berikut. Pertama, peneliti membuat catatan-catatan hasil observasi baik yang intensif partisipatif maupun kausal. Catatan-catatan ini segera dibuatkan deskripsi untuk menggambarkan masalah yang diteliti. Gambaran ini memberikan kepada peneliti kerangka analisis untuk melakukan rekonstruksi: membuat kategori dan konsep, melakukan interpretasi, dan menjelaskan proposisi antar konsep yang dibentuk oleh hubungan tindakan sosial, situasi sosial, dan lingkungan yang melingkupi. Banyak dari deskripsi ini yang menimbulkan pertanyaan yang lebih mendalam untuk dikaji. Dengan tetap melakukan proses triangulasi seperti diuraikan di atas, perpaduan antara berbagai informasi yang ditemukan dari wawancara mendalam dan kajian. Hasil inilah yang kemudian dijadikan basis bagi usaha menjelaskan seluruh temuan penelitian secara sistematis, utuh, menyeluruh, komprehensif, dan bermakna yang menggambarkan pembelajaran blended learning dalam pengembangan IPS.

\section{HASILPENELITIAN}

Blended learning merupakan pembelajaran secara tradisional yang dilengkapi media elektronik atau media teknologi (Bersin, 2004). Thorne dan Mackey (2007), Blended learning merupakan pembelajaran campuran yang memanfaatkan teknologi multimedia, cd-rom, kelas virtual, voicemail, e-mail, video streaming, dan sebagainya.

Adapun rincian komposisi pembelajaran blended learning menurut Elaine Allen, Jeff Seaman, and Richard Garrett sebagai berikut:

Dari tabel diatas dapat disimpulkan bahwa pembelajaran dikatakan online berdasarkan persentase konten apabila lebih dari 80 persen program content nya disampaikan secara online dan dikatakan blended program apabila 30 sampai 79 persen program contentnya disampaikan online.

Menurut Horn \& Staker (2011), Model pembelajaran blended learning terdiri dari:

\section{Model 1: Rotation}

Bentuk umum model rotasi adalah dalam kuliah yang diberikan selama satu semester, siswa kembali pada jadwal tetap antara pembelajaran online, belajar sendiri-sendiri/mandiri dan pembelajaran tatap muka tradisional dengan guru.

2. Model 2: Flex

Program dengan model pembelajaran online yang fleksibel. Pengajar memberikan dukungan yang fleksibel sesuai dengan kebutuhan personal melalui tutorial dan sesi kelompok kecil

3. Model 3: Self-Blend

Pembelajaran online merupakan sebagian kecil dari kegiatan pembelajaran. Peserta didik memilih sendiri bentuk kursus online untuk melengkapi pembelajaran tatap muka. Pembelajaran online hanya sebagai pelengkap.

4. Model 4: Enriched Virtual

Merupakan pengembangan dari sekolah yang sepenuhnya online, kemudian mengembangkan program blended untuk memberikan siswa pengalaman sekolah tatap muka. Waktu pembelajaran dibagi antara menghadiri kuliah di kampus dan pembelajaran jarak jauh. Pada Model-Enriched Virtual, siswa jarang menghadiri kuliah di kampus setiap hari. 
Pembelajaran secara blended merupakan sesuatu yang cukup popular dimana pada sistem pembelajaran ini, digunakan dalam dunia pendidikan yang mengkombinasikan pembelajaran tatap muka dan pembelajaran secara online, yang menyatukan kegiatan pembelajaran dalam kelas dan buku teks. Berdasarkan kajian yang pernah dilakukan pembelajaran menggunakan sistem blended memberikan siswa lebih banyak kesempatan untuk meningkatkan berbagai pilihan metode pembelajaran yang dapat mereka lakukan dimana dengan proses belajar dilakukan melalui berbagai media yang berbeda dan dengan pemilihan waktu yang bervariasi (Dwiyogo, 2016).

Model blended learning yang dikembangan dalam mata kuliah Pengembangan Pembelajaran IPS di Prodi PGSD STKIP Singkawang dilakukan dengan perpaduan tatap muka yang dapat memfasilitasi mahasiswa dengan kehadiran dosen untuk mengembangan rasa kehadiran dan kenyamanan sosial, dalam tatap muka dilakukan untuk membahas kesulitan- kesulitan mahasiswa dalam proses pembelajaran. Dalam proses pembelajaran menggunakan modul offline mengenai konsep- konsep dasar IPS di SD sehingga mahasiswa diharapkan mampu menggunakan teknologi secara offline. Pembelajaran di kelas juga dilaksanakan dengan model online dengan memanfaatkan edmodo sebagai sarana berinteraksi ketika mahasiswa tidak di kampus. Edmodo dapat digunakan sebagai sarana mahasiswa bertanya, mengirimkan tugas, dan dosen dapat juga mengirimkan bahan dan tugas melalui edmodo.

Modul offline yang dibuat dengan aplikasi flip book maker berisi materi- materi IPS yang harus dikuasai mahasiswa. Berdasarkan hasil wawancara kepada dua dosen dan lima mahasiswa bahwa modul yang digunakan dalam upaya penerapan pembelajaran blended learning layak digunakan.

\section{REFERENCES}

Bersin, Josh. The Blended Learning Book: Best Practices, Proven Methodologies, and Lessons Learned. 2004. San Francisco, John Wiley \& Sons, Dabbagh, N. and Ritland. B. B. (2005). Online Learning, Concepts, Strategies And Application. Ohio: Pearson.
Dwiyogo, D, Wasis. 2016. Pembelajaran Berbasis Blended Learning. Malang: Wineka Media.

Elaine Allen, Jeff Seaman, \& Richard Garrret. 2007. Blending In The Extent and Promoise of Blended Education In The United States. United State: Sloan-C, Graham, C.R. 2005. Blended Learning System. Definisi, Current, and Future Directions. dalam The Hand Book of Blended Learning.

Horn, M. B \& Staker, H. 2011. The Rise of K-12 Blended Learning. Innosight Institute. Public Impact.

Thorne, Kaye and David Mackey, Everything You Ever Needed to Know About Training. 2007. London: Kogan Page Publishers. 